\title{
Article
}

http://dx.doi.org/10.11646/phytotaxa.175.2.5

\section{Oyedaea bahiensis, a new synonym in the Brazilian Heliantheae (Asteraceae)}

\author{
MARA ANGELINA GALVÃO MAGENTA ${ }^{1} \&$ BENOÎT LOEUILLE ${ }^{2}$ \\ ${ }^{1}$ Departamento de Botânica, Universidade Santa Cecília, Rua Oswaldo Cruz 277, Boqueirão, 11045-90, Santos, SP, Brazil; email: \\ maramagenta@unisanta.br \\ ${ }^{2}$ Departamento de Botânica, Instituto de Biociências, Universidade de São Paulo, Rua do Matão 277, 05508-090, São Paulo, SP, Bra- \\ zil; email: benoit.loeuille@gmail.com
}

\begin{abstract}
The taxonomic status of Oyedaea bahiensis is clarified. This name is placed here to the synonymy of Aspilia martii, which is described and illustrated. The names Oyedaea angustifolia and O. bahiensis are lectotypified.
\end{abstract}

Key words: Aspilia, Compositae, nomenclature, taxonomy, typification

\section{Introduction}

In the course of preparation of an identification key for the Heliantheae occurring in Brazil, the taxonomic status of Oyedaea bahiensis Baker (1884: 206) has been re-evaluated. All but one Brazilian species of Oyedaea have been transferred to Dimerostemma Cassini (1817: 11) when Robinson (1984) restricted the concept of Oyedaea Candolle (1836: 576) to the species having the cypsela body constricted above into a neck, and the distribution restricted to the Andes (Robinson 1984; Pruski 1996; Moraes \& Semir 2009). By its neckless cypsela and Brazilian distribution Oyedaea bahiensis does not fit the generic concept of Oyedaea. On the other hand, it does not match Dimerostemma either, due to the absence of an outer series of leaf-like phyllaries and pappus awns not continuous with the cypsela margins (Moraes \& Semir 2009).

Oyedaea bahiensis has sterile ray florets and cypselae with a truncate apex and a constricted apical crown bearing all the pappus elements as well as a lateral basal scar. These are characters of the genus Aspilia Petit-Thouars (1806: 12) (Santos 2001). The placement of Aspilia to the synonymy of Wedelia Jacquin (1760:28) by Robinson (1992) and Turner (1992) is highly controversial. Awaiting for phylogenetic studies including these taxa to clarify the generic status of the Brazilian species of Aspilia, we prefer to consider Aspilia as a distinct genus as many authors dealing with the South American Heliantheae do (Santos 2001; Silva and Santos 2010; Hind 2011; Nakajima et al. 2014). It is interesting to note that Blake (1921) had already suggested that Oyedaea bahiensis could belong to Aspilia, but having only seen a sketch of the type material at K, he maintained it in Oyedaea.

The linear to linear-lanceolate leaves and outer phyllaries with caudate apices of Oyedaea bahiensis caught our attention and made us compare that species with Aspilia martii Baker (1884: 195). Evidence from our analysis of herbarium collections that could match one or both species, including their nomenclatural types, shows that these plants occur in a common geographic area and share the same morphological features (hispid plant with decumbent habit, leaves sessile, blade linear, linear-lanceolate or lanceolate, heads subtended by a pair of foliaceous bracteoles, phyllaries lanceolate in two series, cypselae with lateral projections similar to wings and pappus with two awns and squamellae fused into a short corona), leading to the conclusion that both taxa are conspecific. Hence $O$. bahiensis is relegated to the synonymy of $A$. martii. The mistake made by Baker to describe the same taxon in different genera, was probably due to the presence of shoulders with projections resembling the wings found in the cypselae of Oyedaea. In addition, the author have ignored the characteristic cypsela basal scar of the genus Aspilia. 
of Oyedaea angustifolia Gardner (1848: 293). However, Gardner 2216 is represented at K by one specimen from the Herbarium Hookerianum (K000054420) and by another from the Herbarium Benthamianum (K000054424). The designation of Santos (2001) cannot be considered as lectotypification (see Art. 7.10 in McNeill et al. 2012). Gardner worked on his own set of duplicates at BM or on the set of Hooker, especially for the lost Goiás collection (Hind 2012), and both sets comprise the original material. The sheet at K from the Herbarium Hookerianum (K000054420) has more detailed information of the locality matching with the protologue and is chosen here as the lectotype of $O$. angustifolia.

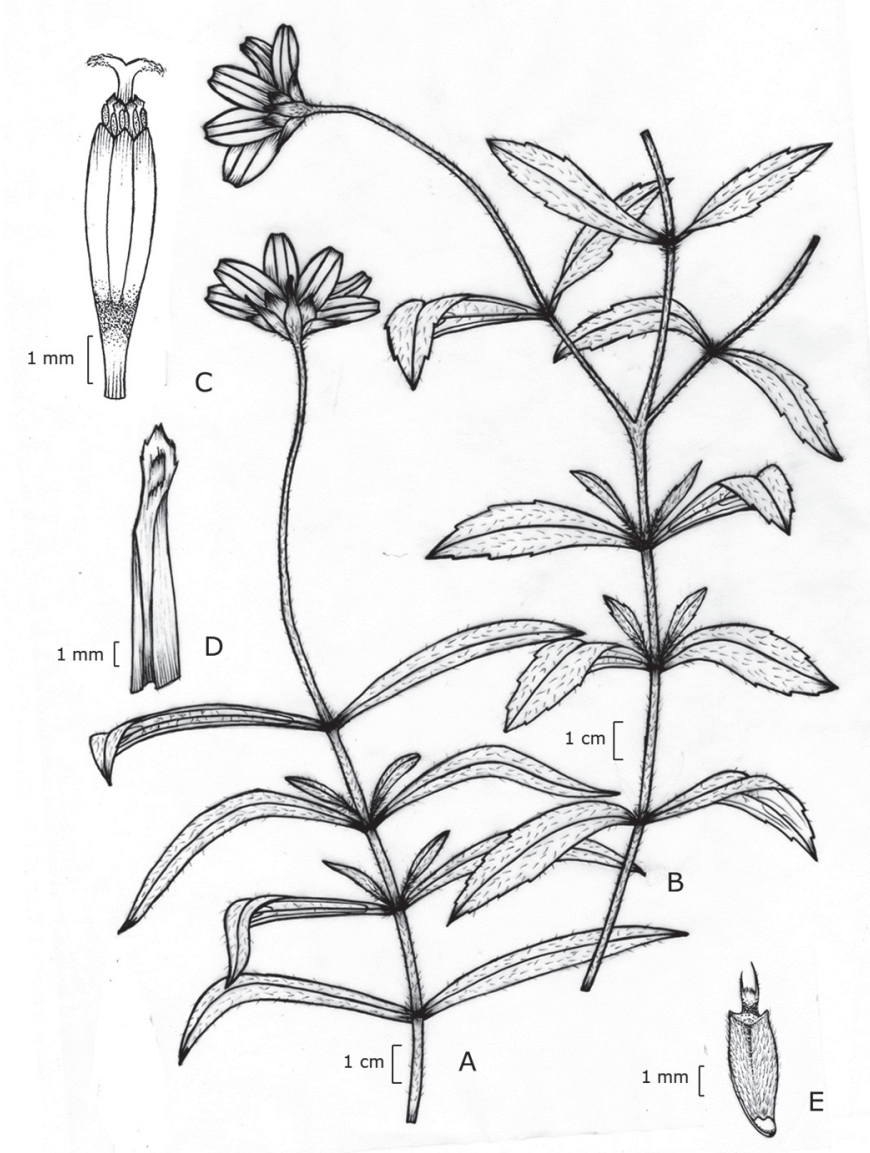

FIGURE 4. Aspilia martii. A, B. Flowering branches. C. Disk floret. D. Palea. E. Cypsela with pappus. A-B. from Martius s.n. (12075) (M), C-D. from Guedes et al. 11197 (SPF), E. from Sousa 130 (RB).

\section{Acknowledgements}

The authors would like to thank the Botanische Staatssammlung München for providing digital images of the holotype of Aspilia martii Baker and the lectotype of Oyedaea bahiensis Baker, and the Board of Trustees of the Royal Botanic Gardens, Kew for providing a digital image of the lectotype of Oyedaea angustifolia. The drawing was prepared by Kellen D. Padovani from Departamento de Botânica, Universidade Santa Cecília.

\section{References}

Baker, J.G. (1884) Compositae IV. Helianthoideae. In: Martius, C.F.P. von \& Eichler, A.W. (Eds.) Flora brasiliensis 6(3). F. Fleischer, Münich, Vienna, Leipzig, pp. 137-268.

Blake, S.F. (1921) Revision of the genus Oyedaea. Contributions from the United States National Herbarium 20: 411-422.

Candolle, A.P. de (1836) Heliantheae. In: Candolle, A.P. de (Ed.) Prodromus Systematis Naturalis Regni Vegetabilis 5. Treuttel et Würtz, Paris, pp. 534-634. 
http://dx.doi.org/10.5962/bhl.title.286

Cassini, H. (1817) Aperçu des genres nouveaux formés par M. Henri Cassini dans la famille des Synanthérées, second fascicule. Bulletin des Sciences, par la Société Philomatique de Paris 1817: 10-13.

Gardner, G. (1848) Contributions towards a flora of Brazil, being the distinctive characters of some new species of Compositae, belonging to the tribe Senecionideae. London Journal of Botany 7: 286-296.

Hind, D.J.N. (2011) An annotated preliminary checklist of the Compositae of Bolivia (Version 2). Available from: http://www.kew.org/ science/tropamerica/boliviacompositae/ (accessed 30 January 2014).

Hind, D.J.N. (2012) George Gardner's Catalogue of Brazilian Plants. A transcription of George Gardner's manuscript. Available from: http://www.kew.org/science/tropamerica/gardner/catalogue.html (accessed 30 January 2014).

Jacquin, N.J. (1760) Enumeratio systematica plantarum. T. Haak, Lugduni Batavorum [Leiden], 41 pp.

McNeill, J., Barrie, F.R., Buck, W.R., Demoulin, V., Greuter, W., Hawksworth, D., Herendeen, P.S., Knapp, S., Marhold, K., Prado, J., Prud'homme van Reine, W.F., Smith, G.F., Wiersema, J.H. \& Turland, N.J. (Eds.) (2012) International Code of Nomenclature for algae, fungi and plants (Melbourne Code). Regnum Vegetabile 154. Koeltz Scientific Books, Koenigstein, 240 pp.

Moraes, M.D. de \& Semir, J. (2009) A revision of Brazilian Dimerostemma (Asteraceae, Heliantheae, Ecliptinae), with a new species and taxonomic adjustments. Brittonia 61: 341-365.

http://dx.doi.org/10.1007/s12228-009-9083-y

Nakajima, J., Loeuille, B., Heiden, G., Dematteis, M., Hattori, E.K.O., Magenta, M., Ritter, M.R., Mondin, C.A., Roque, N., Ferreira, S.C., Teles, A.M., Borges, R.A.X., Monge, M., Bringel Jr., J.B.A., Oliveira, C.T., Soares, P.N., Almeida, G., Schneider, A., Sancho, G., Saavedra, M.M., Liro, R.M., Souza-Buturi, F.O., Pereira, A.C.M., Moraes, M.D., Silva, G.A.R., Medeiros, J.D. \& Siniscalchi, C.M. (2014) Asteraceae in Lista de Espécies da Flora do Brasil. Jardim Botânico do Rio de Janeiro. Available at http://floradobrasil.jbrj. gov.br/jabot/floradobrasil/FB55 (accessed 30 January 2014).

Petit-Thouars, L.M.A. du (1806) Genera Nova Madagascariensia. Paris, 29 pp.

Pruski, J. (1996) Compositae of the Guayana Highland XI. Tuberculocarpus gen. nov. and some other Ecliptinae (Heliantheae). Novon 6: 404-418. http://dx.doi.org/10.2307/3392050

Robinson, H. (1984) Studies in the Heliantheae (Asteraceae). XXIX. Additions to the genus Dimerostemma. Proceedings of the Biological Society of Washington 97: 618-626.

Robinson, H. (1992) New combinations in Elaphandra Strother (Ecliptinae-Heliantheae-Asteraceae). Phytologia 72: $144-151$.

Santos, J.U. (2001) O gênero Aspilia Thou. (Asteraceae-Heliantheae) no Brasil. Museu Paraense Emílio Goeldi. Belém, 301 pp.

Silva, G.A.R. \& Santos, J.U. (2010) Novos registros de espécies da subtribo Ecliptinae (Heliantheae-Asteraceae) para a Amazônia brasileira. Acta Amazonica 40: 499-508. http://dx.doi.org/10.1590/s0044-59672010000300008

Turner, B.L. (1992) New names and combinations in New World Wedelia (Asteraceae-Heliantheae). Phytologia 72: 389-395. 